by Ewelina Mocior ${ }^{l}$, Bartlomiej Rzonca ${ }^{l}$, Janusz Siwek ${ }^{l}$, Joanna Plenzler ${ }^{l}$, Eliza Placzkowska ${ }^{1}$, Natalia Dabek ${ }^{l}$, Barbara Jaskowiec ${ }^{l}$, Piotr Potoniec ${ }^{2,3}$, Sylwia Roman ${ }^{1}$, Dominik Zdziebkol

\title{
Determinants of the distribution of springs in the upper part of a flysch ridge in the Bieszczady Mountains in southeastern Poland
}

\author{
${ }^{1}$ Jagiellonian University, Institute of Geography and Spatial Management, 7 Gronostajowa Str., 30-387 Krakow, Poland. \\ E-mail: ewelina.mocior@uj.edu.pl \\ 2 Jagiellonian University, Institute of Geological Sciences, 2a Oleandry Str., 30-063 Krakow, Poland. \\ ${ }^{3}$ Pedagogical University of Cracow, 2 Podchorazych Str, 30-084 Krakow, Poland.
}

(Received: April 30, 2014; Revsied accepted : November 11, 2014)

Distribution of groundwater outflows (springs) is determined by a number of natural factors - the most important factor being geological structure. However, the relationship between spring location and environmental characteristics in flysch areas has not been studied extensively. The purpose of the paper is to analyze the determinants of springs location in a flysch massif based on a database of springs created in the course of detailed field mapping. The study area consisted of the Polonina Wetlinska Massif in the Bieszczady Mountains in southeastern Poland. In the period 2010-2012, all springs found above 900 meters of elevation were mapped in the study area. Next, the study area was divided into catchments and square polygons (side: $100 \mathrm{~m}$ ). Statistical tests were then used to analyze the distribution of springs across the study area and its dependence on terrain morphometry.

Research has shown that the distribution of springs in flysch areas is affected by complex determinants consisting of interdependent geological and morphological factors. The most important factor appears to be the layering of rocks relative to the slope of the given mountain, which affects both the number and discharge of springs. Some springs arise due to tectonic faults and fractures. In addition, the very presence of any slope positively affects the probability of the occurrence of a spring in a given area.

\section{Introduction}

The distribution and natural characteristics of springs serve as proof of water resources and groundwater circulation patterns in a given geographic area. However, the mapping of springs and circulation patterns is very laborious and time-consuming. Furthermore, groundwater supplies and consequently spring density change from season to season as well as in the long term due to climate change and other factors (Buczynski and Wcislo, 2013). This is why the hydrology of springs needs to be observed and documented on an ongoing basis in order to provide a credible basis for analysis. A detailed understanding of the factors determining spring distribution may allow for the prediction of spring distribution in other regions of the world that have a similar geological structure. The use of GIS techniques is very helpful in such efforts. The analysis of local geology and morphometry is especially important in the process of predicting the location of springs.

A number of key environmental factors determine the location of springs including type of parent material and thickness of young deposits, which is associated with the permeability of the parent material. In general, the presence of flysch rocks does not favor springs (Corsini et al., 2009). On the other hand, distance from thrusts and faults exhibits a strong positive correlation with spring density (Corsini et al., 2009; Buczynski and Rzonca, 2011; Ozdemir, 2011; Bense et al., 2013). Many springs are found at the point of contact between permeable and non-permeable rock layers (Corsini et al., 2009; Ozdemir, 2011). In the case of flysch, the significant permeability of sandstone relative to that of shale produces a large number of springs at the point of contact between the two layers. This is especially true when sandstone layers are interbedded with layers of shale (Jetel, 1985; Rzonca et al., 2008) as well as at the point of contact between flysch rocks and less permeable geological layers (Baker et al., 2001). According to Corsini et al. (2009), spring formation is also more likely in cases where the gradient of parent material layers generally follows the slope of the mountain, with an angle of dip greater than the slope of the mountain. On the other hand, Rzonca et al. (2008) state that spring formation in a flysch environment is favored by an angle of dip opposite to that of the slope of the mountain.

The identification of areas with a large probability of the occurrence of springs is aided by characteristics such as elevation, 
slope, and the stream power index. The slope interval that most strongly favors the occurrence of springs is $15-25^{\circ}$. A negative correlation with the occurrence of springs has been noted for plan curvature, drainage density, and the wetness index (Ozdemir, 2011). According to Corsini et al. (2009), two other key factors are large scale rock slides and earth flows. Research has shown that slides strongly affect variations in the hydrogeological properties of flysch rocks (Ronchetti et al., 2009). The link between the occurrence of some springs and mass movement has also been confirmed by research of landslides in flysch areas (Mikoš et al., 2006; Alexandrowicz and Margielewski, 2010).

Data on the physical and chemical properties of spring water are helpful in the analysis of the determinants of the distribution of springs. Mineral content, conductivity, and to some degree temperature make it possible to learn more about the residence time of groundwater (Celle-Jeanton et al., 2009; Chie and Xue, 2011).

While the determinants of the distribution of springs and their properties have been analyzed quite frequently for karst areas (Grasso et al., 2003; Barfield et al., 2004; Fiorillo et al., 2007; Zagana et al., 2011; Prtoljan et al., 2012; Magal et al., 2013; Matis et al., 2013), far fewer research papers are available on this subject for flysch areas. Water circulation patterns in layers formed of sandstone and shale complexes, which tend to affect the uneven distribution of springs in flysch areas, have not been studied extensively. In light of the above, more research is needed on the factors affecting the distribution of springs in areas dominated by flysch rocks. This paper is an attempt to help accomplish this goal. The purpose of this paper is to study in detail the determinants of the distribution of springs in flysch massifs using a database of springs following detailed field mapping studies.

\section{Study area}

An example of a region formed of flysch rocks is the High Bieszczady Mountains, which are part of the Eastern Carpathian mountain chain in southeastern Poland (Fig. 1). The High Bieszczady are characterized by a unique rock layer pattern (namely, a high dip of rock layers) that strongly affects the mechanism and rate of groundwater circulation. The distribution of springs is an intermediate effect of the groundwater circulation pattern in the region (Rzonca et al., 2008; Siwek et al., 2009). Finally, while there are many springs in the Bieszczady Mountains, as is the case in other parts of the flysch Carpathians, most yield little water (Chelmicki et al., 2011).

The Polonia Wetlinska Massif (elevation: 1,255 m) in southeastern Poland was selected as the study area. The massif is characterized by geology and relief that mirror those of the entire Bieszczady mountain chain. However, this region may be considered particularly valuable in the context of other flysch regions due to the presence of high-discharge springs at relatively high elevations (close to ridge top), which is unusual in flysch areas. The study area was narrowed down to the top part of the Polonina Wetlinska Massif - an area of $18.34 \mathrm{~km}^{2}$. The 900 -meter contour line was used as the boundary line of the study area (Fig. 1). The Polonina Wetlinska Massif is a section of the High Bieszczady Mountains - a part of the Eastern Carpathian mountain chain (Balon et al., 1995). It is a midsize mountain range with elevations ranging from 800 to 1,346 meters

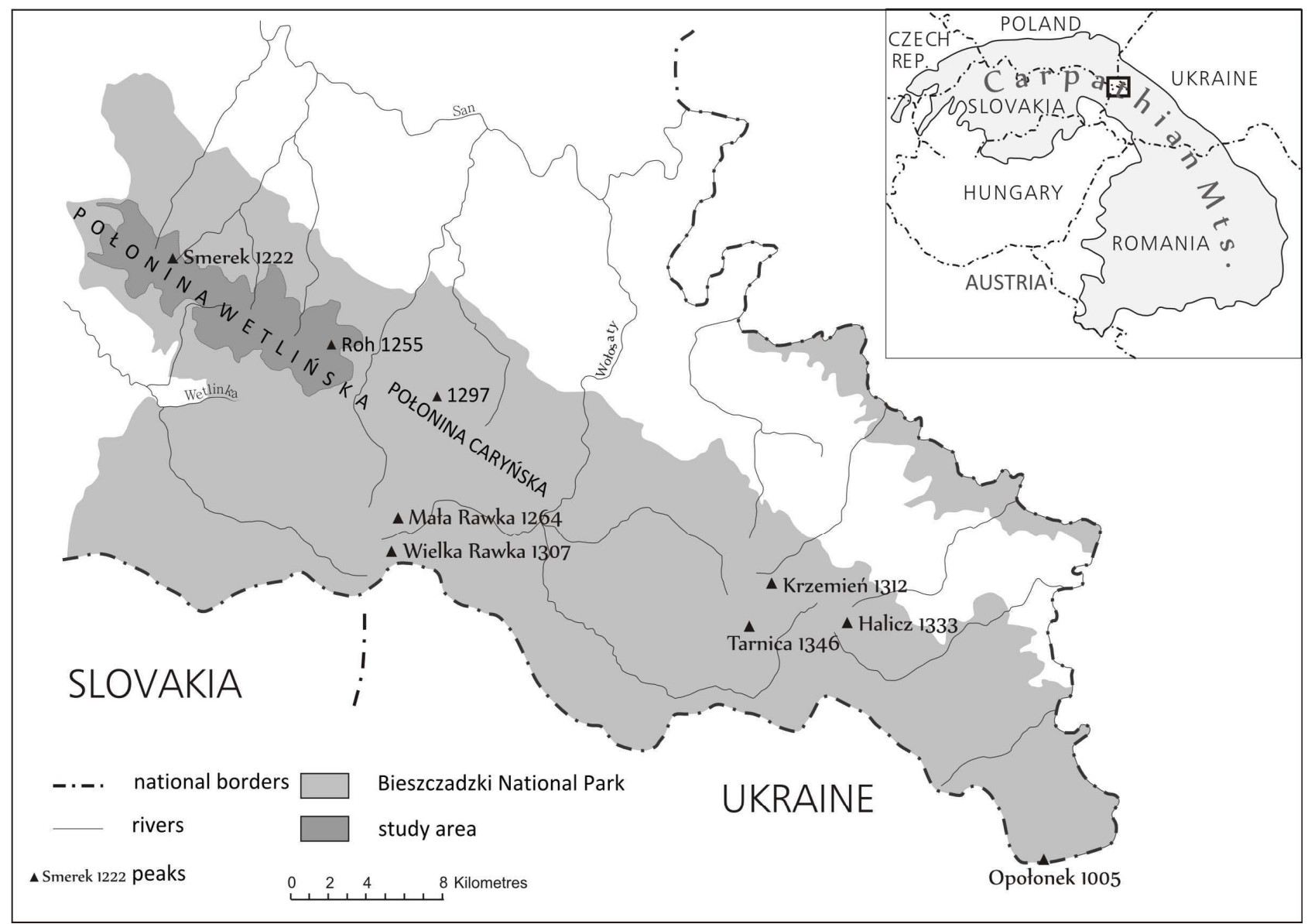

Figure 1. Study area. 
and height differences between 400 and 600 m (Raczkowska et al., 2012).

The High Bieszczady are part of the Outer Carpathian mountain chain - the outermost section of Alpine folding in the Carpathians which had formed between the Oligocene and the Middle Miocene (Földvary, 1988; Schmid et al., 2008). The entire Outer Carpathians are formed of flysch rocks - interlayered sandstone, conglomerate, siltstone, and claystone, with a small amount of carbonate and silicic rock. These layers had been completely separated from bedrock and shifted north in the form of nappes yielding a number of distinct tectonic-facial units (Oszczypko, 2006). The High Bieszczady are located along the boundary of two major structural units - the Dukla unit and the Silesian unit (Haczewski et al., 2007).

The top of Polonina Wetlinska is formed of Krosno layers (Silesian unit) dipping northeast at an angle of $30^{\circ}$ to $60^{\circ}$ (Fig. 2). Each Krosno layer consists of thick (up to $200 \mathrm{~m}$ ) packets of Otryt sandstone partitioned by thin layers of shale (Haczewski et al., 2007). However, no detailed data are available on the location of courses of contacts between layers of sandstone and shale on the slopes. Rock series are usually split by small transverse faults (Fig. 4). In addition, flysch sediments are characterized by the presence of a large number of fractures. Quaternary slope sediments and alluvia can be found in the study area (Mastella and Tokarski, 1995; Haczewski et al., 2007).

High Bieszczady relief is closely linked with lithology and tectonics. Parallel ridges closely mirror key geological patterns in the region (NW-SE orientation) and are fragmented by subsequent valleys running parallel to ridgelines and transverse valleys cutting through ridgelines as well as smaller consequent valleys, thus creating a grid pattern of rivers and streams. The region's relief includes clifftype landforms found on ridge tops as well as step-type landforms found on slopes (Starkel, 1966; Kukulak, 2004). The flysch structure of the Bieszczady Mountains favors a variety of forms of mass movement including landslides (Margielewski, 2006), which are typical for Outer Western and Eastern Carpathians (Lajczak et al., 2014).

The Bieszczady Mountains are located in a temperate climate zone (Peel et al., 2007). Mean annual temperatures at higher elevations across Polonina Wetlinska range from 1 to $4^{\circ} \mathrm{C}$ (Nowosad, 1995). Mean annual precipitation totals range from $1,100 \mathrm{~mm}$ at lower elevations to more than $1,400 \mathrm{~mm}$ at higher elevations across the Polonina Wetlinska (Laszczak et al., 2011). The study area is drained by streams and rivers in the San drainage basin or that of its tributary - the Solinka. The density of rivers and streams in both drainage basins ranges between 2 and $3 \mathrm{~km} \mathrm{~km}^{-2}$. Mean terrain gradients range from 25 to $31^{\circ}$. Mean specific discharge ranges from 14 to $40 \mathrm{dm}^{3} \mathrm{~s}^{-1} \mathrm{~km}^{-2}$ (Mocior et al., 2011). Groundwater in the Bieszczady Mountains is found within two aquifers: (1) Cretaceous-Tertiary Carpathian flysch, (2) Quaternary alluvia - mostly in larger valleys.

The flysch water table, recharged primarily by the infiltration of precipitation water, formed in sandstone interlayered with poorly permeable clay and marl shale. The filtration index for Krosno sandstone is relatively low and ranges from $2.4 \times 10^{-7}$ to $1.4 \times 10^{-6} \mathrm{~m} \mathrm{~s}^{-1}$ (Chowaniec et al., 1983; Chowaniec, 2011). Low retention capacity results in shallow groundwater circulation, which leads to a rapid response to atmospheric precipitation by the water table. The same is true of spring discharge (Jaskowiec et al., 2011). Base groundwater discharge ranges from 1 to $6 \mathrm{dm}^{3} \mathrm{~s}^{-1} \mathrm{~km}^{-2}$ and reaches the highest values in catchments located on the northern slopes of Polonina Wetlinska (Plenzler et al., 2010).

The distribution of springs and their properties have not been studied extensively thus far in the Bieszczady Mountains. Only small areas in the region have been mapped in the context of springs (Rzonca et al., 2008; Lajczak et al., 2010). Two types of groundwater outflows have been identified in the Bieszczady Mountains: (1) springs, (2) bog springs. Most springs in the region yield relatively little discharge - usually less than $0.1 \mathrm{dm}^{3} \mathrm{~s}^{-1}$ and rarely more than $1 \mathrm{dm}^{3} \mathrm{~s}^{-1}$ (Rzonca et al., 2008; Lajczak et al., 2010; Jaskowiec et al., 2011). Many lowdischarge springs function seasonally, which manifests itself in the form of seasonally dry valleys (Siwek et al., 2009). Location and density data (23.56 springs per square $\mathrm{km}$ ) were collected via hydrological mapping in the relatively small Upper Wolosatka

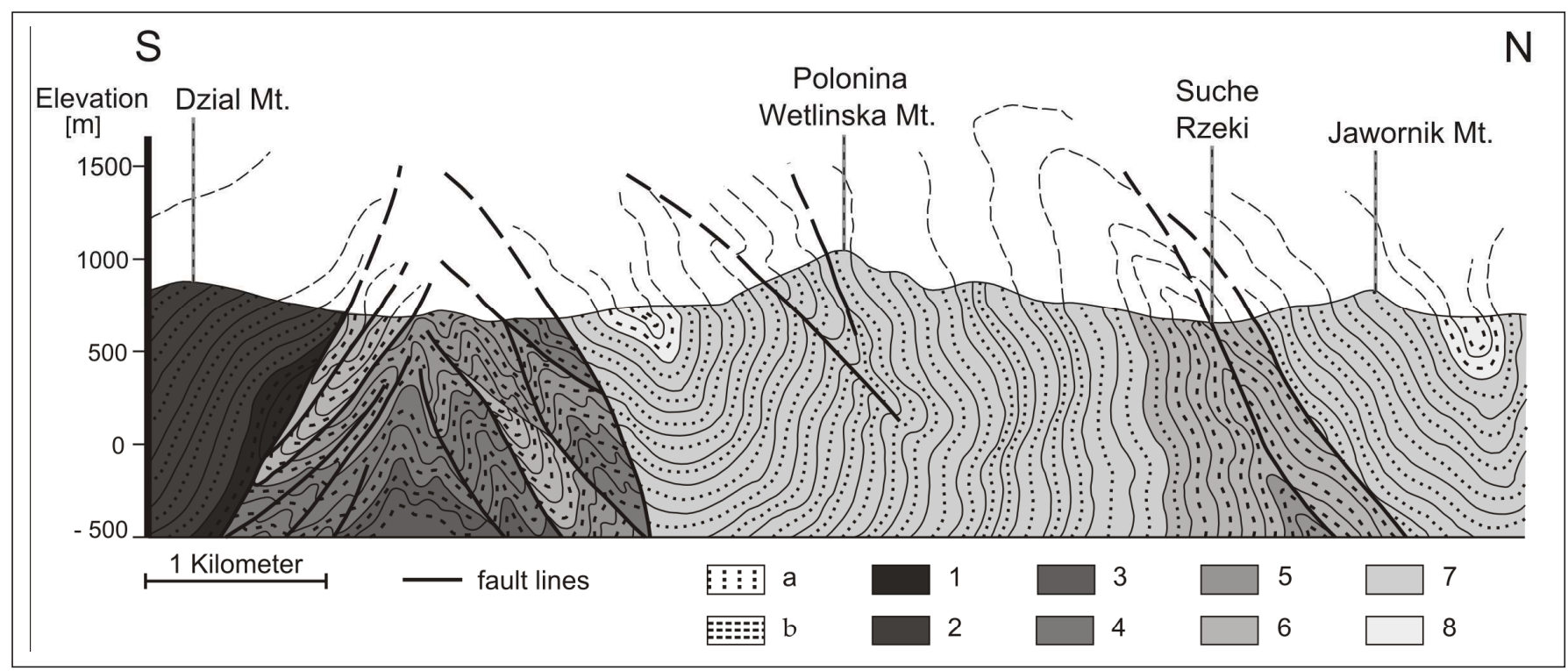

Figure 2. Geological cross section of the Polonina Wetlinska Massif and neighboring mountain ridges. (Source: Mastella, Tokarski, 1995). Legend: 1 - Lupkow layers, 2 - cisna layers, 3 - hieroglyphic layers, 4-menilite layers, 5 - transitional layers; krosno layers: 6 - sandstoneshale core, 7 - otryt sandstone, 8 - shale-sandstone core; $a$ - sandstone, $b$ - shale 
catchment located in the Bieszczady region. Selected relationships between spring location, geological structure, and relief were identified in the catchment. Research in the catchment has shown that many springs appear to be linked to the irregular network of fractures and tectonic discontinuities in the area. Another key factor is the relationship between the angle of dip of rock layers and the slope of the mountain (Rzonca et al., 2008). Some of the factors behind the chemistry of spring water were also explained for the Upper Wolosatka catchment. The three most important factors were shown to be groundwater aquifer, lithology and elevation above sea level, which affects precipitation amounts, as well as the nature of natural plant communities found in areas recharging the aquifer (Siwek et al., 2013).

\section{Materials and Methods}

\section{Data collection and processing methods}

A GPS receiver was used to map springs in the field in the period 2010-2012 (Table 1). The research was carried out during a relatively homogeneous hydrological period - low stream discharge in the summer season, which corresponds to low to mean values of spring discharge. Specific electrical conductivity (SEC) and spring water temperature were measured as the secondary indicators of water residence time. Spring discharge was measured volumetrically. Three measurements were made for each spring and the results were then averaged if the differences were smaller than $5 \%$. If the differences were larger, then measurements were repeated in order to obtain closer values. Springs noted in the study area were classified as either point springs, characterized by a concentrated outflow, or bog springs, which usually give an outflow from a small swamp (commonly bog). Observations were made of exposure, plant communities, and landforms yielding groundwater including boulders (diameter of particles higher than $600 \mathrm{~mm}$ ), debris (grain size range from 2 to $600 \mathrm{~mm}$ ), and fine weathering material (grain size less than $2 \mathrm{~mm}$ ). All the data collected were carefully noted for later use.

Table 1. Dates and areas of spring mapping in the study area.

\begin{tabular}{|c|c|l|c|}
\hline $\begin{array}{c}\text { Year of } \\
\text { mapping }\end{array}$ & $\begin{array}{c}\text { Dates of } \\
\text { mapping }\end{array}$ & \multicolumn{1}{|c|}{$\begin{array}{c}\text { Catchments } \\
\text { mapped }\end{array}$} & $\begin{array}{c}\text { No. of springs } \\
\text { mapped }\end{array}$ \\
\hline 2010 & $1-10.07$ & $1,3,4,5,6,7,8$ & 543 \\
2011 & $2-11.07$ & $2,9,10,11,13,14,15$ & 297 \\
2012 & $1-09.09$ & 12 & 39 \\
\hline
\end{tabular}

Additional data were collected for the purpose of creating a database of springs, which included topographic parameters of the study area (calculated for catchments and square polygons) obtained from a digital elevation model (resolution: $10 \mathrm{~m}$ ), generated using triangulated irregular networks (TINs), and from CORINE Land Cover. ArcGIS 10 software was used to calculate the parameters.

The data were standardized in order to be comparable. Skewness and curtosis were analyzed in order to assess statistical distributions. Data not characterized by a normal statistical distribution were converted into logarithms. Statistical distributions were analyzed using the Shapiro-Wilk and Lilliefors tests at a $p<0.05$ level of significance. Data characterized by a normal distribution were subjected to parametric statistical analysis. Other data were analyzed using nonparametric tests. The distribution of springs was analyzed at two spatial scales - local and regional.

\section{Methods for evaluating regional patterns of spring distribution}

The study area was defined as selected fragments of the smallest catchments in the region of interest, as demarcated using the Polish Hydrographic Classification (Czarnecka, 2005; Fig. 3). Minor fragments, where no springs had been identified, were removed, as shown in Fig. 3, because they were not representative and their metrics cannot be compared with those with springs. Fifteen catchments were identified in this manner. The following data were then collected for each catchment - surface area (sq. km), number of springs, density of springs (springs per sq. $\mathrm{km}$ ), number of springs per 50 meters of elevation, mean elevation, minimum elevation, maximum elevation, mean slope, minimum slope, maximum slope, percentage woodland, predominant exposure (macro-exposure) based on a map (N, NE,E, SE, S, SW, W, NW), mean topographic wetness index (Eq. 1); and index value calculated for $10 \times 10 \mathrm{~m}$ pixels and averaged for the entire catchment.

$$
\mathrm{TWI}=\ln \left(\mathrm{A}_{\mathrm{s}} / \operatorname{tg} \beta\right)
$$

where $A_{s}$ - specific catchment area per unit contour length; $\beta$-slope angle

Next, the correlation between spring density and selected catchment parameters was analyzed for catchments characterized by a normal distribution - percentage woodland, maximum elevation, elevation differences, macro-exposure. The Kruskal-Wallis test was used to analyze spring density and morphometric parameters of catchments across the study area. Catchments were divided into four groups in terms of spring density based on the lower quartile, median, and upper quartile (Fig. 5).

\section{Methods for evaluating local patterns of spring distribution}

A network of square polygons measuring 100x100 meters was delineated across the Polonina Wetlinska mountain ridge, with at least half of the surface area of each polygon falling within the desired study area. The following parameters were calculated for each polygon - number of springs, density of springs, minimum elevation, maximum elevation, mean elevation, elevation difference, mean terrain slope, predominant exposure, topographic wetness index, percentage woodland.

An analysis of variance (ANOVA) was performed to determine the significance of differences between square polygons with different numbers of springs $(0,1,2,3,4$ or more). The post-hoc Scheffe test was used to determine the significance of differences $(p \leq 0.05)$.

\section{Results}

\section{Characteristics of springs}

A total of 879 springs were mapped across Polonina Wetlinska, which yields a spring density of 47.98 per square kilometer. Most of the mapped springs were point springs $(76 \%)$, while some were bog springs $(24 \%)$. The most commonly encountered springs were lowdischarge springs - less than $0.1 \mathrm{dm}^{3} \mathrm{~s}^{-1}$ (54\% of springs). Few highdischarge springs were noted - only $4 \%$ in the 1.0 to $2.0 \mathrm{dm}^{3} \mathrm{~s}^{-1}$ category and $2 \%$ in the 2.0 to $5.0 \mathrm{dm}^{3} \mathrm{~s}^{-1}$ category (Table 2). Six springs $(0.6 \%)$ were found to yield more than $5 \mathrm{dm}^{3} \mathrm{~s}^{-1}$. The largest 


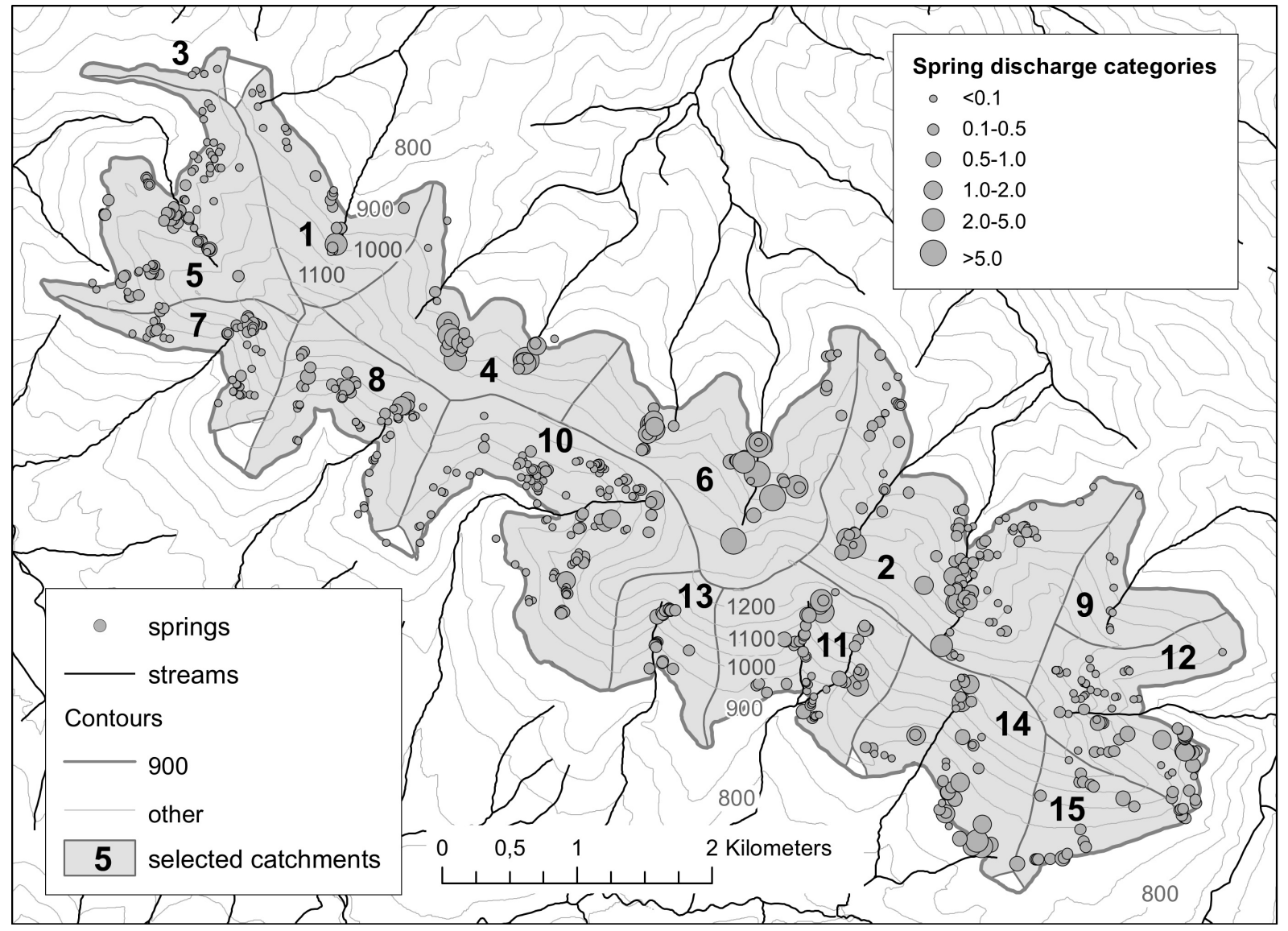

Figure 3. Location of springs in selected catchments in Polonina Wetlinska according to spring dicharge categories based on singular measurements.

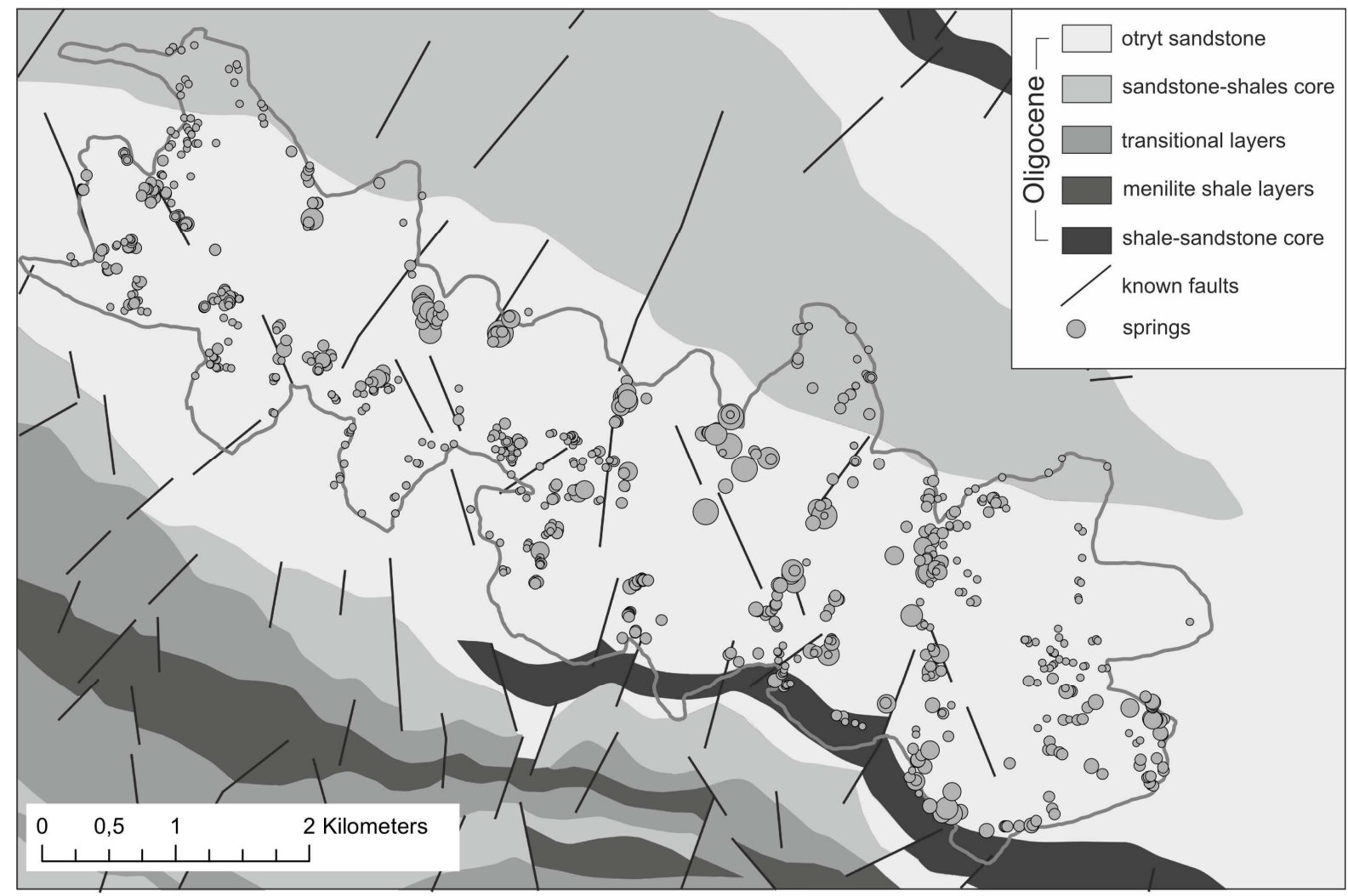

Figure 4. Location of springs in Polonina Wetlinska range superimposed on geological map (Geological map source: Mastella and Tokarski, 1995). 
Table 2. Number of springs by discharge category.

\begin{tabular}{|l|r|r|}
\hline $\begin{array}{c}\text { Discharge category } \\
{\left[\mathrm{dm}^{3} \mathrm{~s}^{-1}\right]}\end{array}$ & Count & Percentage \\
\hline$<0.1$ & 470 & 53.5 \\
$0.1-0.5$ & 318 & 36.2 \\
$0.5-1.0$ & 39 & 4.4 \\
$1.0-2.0$ & 29 & 3.3 \\
$2.0-5.0$ & 17 & 1.9 \\
$>5.0$ & 6 & 0.7 \\
Total & 879 & 100.0 \\
\hline
\end{tabular}

spring was found to yield $19.18 \mathrm{dm}^{3} \mathrm{~s}^{-1}$. The mean temperature of the studied springs was $8.4^{\circ} \mathrm{C}$. The highest temperature $\left(15.4^{\circ} \mathrm{C}\right)$ was noted for a bog (diameter of more than $30 \mathrm{~m}$ ) situated in a flat area found above 1,100 meters of elevation. The lowest temperature $\left(5.3^{\circ} \mathrm{C}\right)$ was noted for the highest discharge spring in the study area.

Conductivity for water was found to range from 28.2 to $287.0 \mu \mathrm{S}$ $\mathrm{cm}^{-1}$, while the average value for all the studied springs was $130.6 \mu \mathrm{S}$ $\mathrm{cm}^{-1}$. Mean conductivity values were similar for both types of groundwater outflows - point springs and bog springs.

\section{Regional patterns of spring distribution}

A number of the morphometric indicators calculated for small catchments situated across the Polonina Wetlinska Massif exhibit statistically significant correlations with spring density. Spring density is positively correlated with exposure (0.54), and the number of springs is positively correlated with maximum elevation and elevation differences in the catchment (0.6-0.7).

Catchments with the largest spring density (Fig. 5) are characterized by the largest gradients - both mean and maximum gradients - and are found on slopes with a southwestern macroexposure. On the other hand, catchments with the smallest density of springs are located on slopes with a mostly northeastern macroexposure. The lowest density of springs was calculated for northeastern slopes (13-31 springs $/ \mathrm{km}^{2}$ ), while the highest (67-84 springs $/ \mathrm{km}^{2}$ ) for southwestern slopes. In the southeastern part of the studied massif, differences in spring density are less pronounced: 31-67 springs per square $\mathrm{km}$. However, the Kruskal-Wallis test did not confirm that the selected groups of catchments differ significantly in terms of spring density. The test was performed for the number of springs, maximum elevation, mean elevation, minimum gradient, maximum gradient, mean gradient, and percentage woodland. Statistically significant

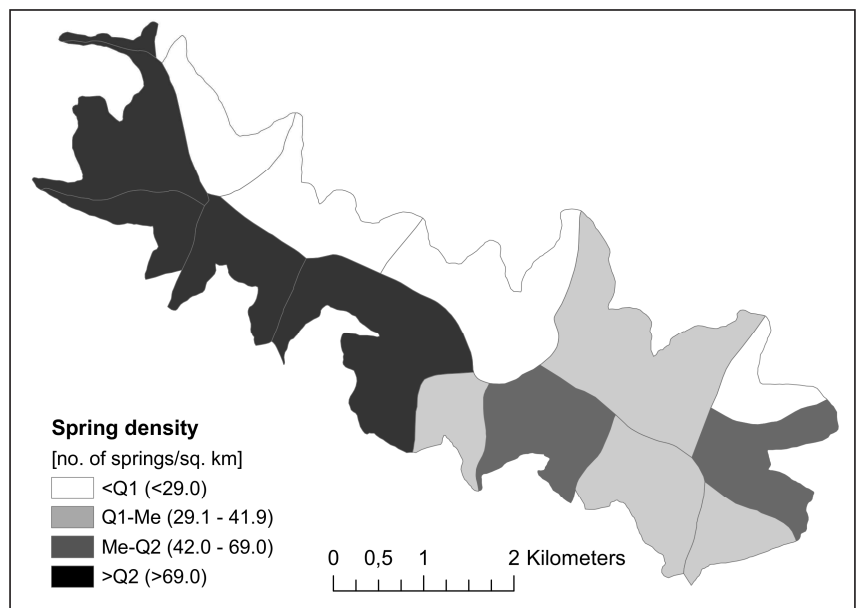

Figure 5. Spring density in the study area. differences were observed for the four samples in the case of exposure $(\mathrm{p}<0.05)$ and the inverse of the topographic wetness index $(\mathrm{p}<0.1)$.

The largest number of springs in the study area (296) were recorded in the lowest elevation category (900-950 m), which had a surface area of $5.2 \mathrm{~km}^{2}$. This gives a spring density of 56.9 springs per square kilometer. The highest spring density $\left(65.2 \mathrm{springs} / \mathrm{km}^{2}\right)$ was calculated for the $1,000 \mathrm{~m}$ to $1,050 \mathrm{~m}$ elevation category. On the other hand, the smallest numbers of springs in the study area were located in the highest elevation categories $(1,100$ to $1,150 \mathrm{~m}$ and above $1,150 \mathrm{~m}$ ). This corresponds to 37 and 15 springs, which yields a spring density of 22.0 and 8.3, respectively. The highest spring was found at an elevation of $1,181 \mathrm{~m}$.

At the catchment level, the largest numbers of springs (30\% to $80 \%$ ) was also found in the lowest elevation category. The remaining three elevation categories usually feature a similar number of springs and are characterized by a similar spring density. The situation is different in the case of a tributary catchment in the area of a lateral

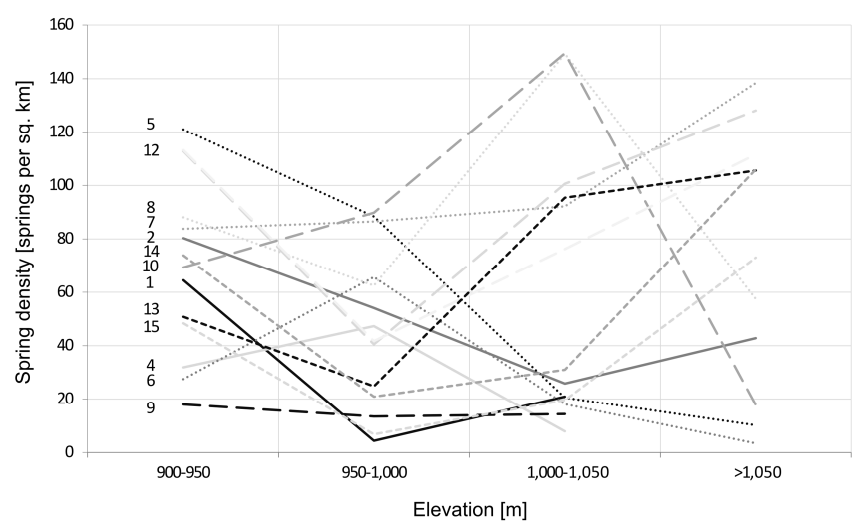

Figure 6. Spring density in selected catchments numbered as in Fig. 3 versus elevation categories.

ridge known as Hnatowe Berdo (no. 10) and in the case of a tributary catchment found close to Orlowicza Pass (no. 8). In both cases, the 1,000 to 1,050 meter elevation category is characterized by the highest spring density (Fig. 6).

\section{Local patterns of spring distribution}

A total of 1,823 square polygons were delineated in the study area, $81 \%$ of which did not contain a spring (Fig. 7). Nine percent of the polygons contained one spring, while five percent contained two springs and two percent contained three springs. Three percent of the studied polygons found above $900 \mathrm{~m}$ of elevation contained four or more springs. The largest number of springs found within one polygon was thirteen. Only one such polygon was identified in the study area.

Spring density does not appear to be directly related to morphometric parameters. A statistically significant difference was noted in mean elevation between polygons without springs and polygons with at least one spring. This means that springs do not normally occur at elevations close to the ridge top. Another significant difference is that of mean terrain gradient in polygons without springs and polygons with three springs. There also exists a significant difference in the mean inverse of the topographic wetness index between polygons without springs and polygons with springs, where polygons without springs are characterized by much larger index values. Polygons featuring different numbers of springs do not 
Table 3. Differences between polygons with different numbers of springs

\begin{tabular}{|c|c|c|c|c|}
\hline Parameters & $\begin{array}{c}\Delta \mathrm{H} \\
{[\mathrm{m}]}\end{array}$ & $\begin{array}{c}\mathrm{H}_{\text {mean }} \\
{[\mathrm{m}]}\end{array}$ & $\begin{array}{c}\mathrm{S}_{\text {mean }} \\
{\left[{ }^{\circ}\right]}\end{array}$ & $\begin{array}{c}\mathrm{TWI}_{\text {mean }} \\
{[-]}\end{array}$ \\
\cline { 1 - 4 } $\begin{array}{l}\text { No. of springs } \\
\text { in polygons }\end{array}$ & & & - & \\
\cline { 1 - 3 } 0 and 1 & - & + & - & + \\
0 and 2 & - & + & - & + \\
0 and 3 & + & - & + & + \\
0 and 4+ & - & + & - & + \\
1 and 2 & - & - & - & - \\
1 and 3 & - & - & - & - \\
1 and 4+ & - & - & - & - \\
2 and 3 & - & - & - & - \\
2 and 4+ & - & - & - & - \\
3 and 4+ & - & - & - & - \\
\hline
\end{tabular}

“+” - presence of significant differences (ANOVA) in the values of parameters in polygons

“-" - lack of significant differences (ANOVA) in the values of parameters in polygons

Parameters: $\Delta H$-elevation differences, $H_{\text {mean }}-$ mean elevation, $S_{\text {mean }}-$ mean gradient, $T W I$ - mean topographic wetness index

significantly differ from one another in terms of morphometric parameters (Table 3 ).

The map of polygons identified by their number of springs shows certain patterns of polygons with at least one spring (Fig. 7). These patterns can be described as elongated zones with lines fitted to represent hypothetical bands of springs. The lines represent two basic directions: NE-SW and $\mathrm{N}-\mathrm{S}$, perpendicular or diagonal to the ridge line (NW-SE; Fig. 8). The NE-SW direction is dominant in the western part of the study area, while the $\mathrm{N}-\mathrm{S}$ direction is dominant in the eastern part. These two directions were then compared with the pattern of faults noted across the Polonina Wetlinska Massif (Mastella and Tokarski, 1995). Faults in the study area usually follow three basic directions: NNW-SSE, NNE-SSW, NE-SW (Fig. 8).

\section{Discussion}

The spatial distribution of springs varies strongly across the flyschtype Polonina Wetlinska Massif. There is a strong relationship between the number and density of springs and macro-exposure. It may be assumed that this relationship results from the monoclinal dip of rock layers ranging from $30^{\circ}$ to $60^{\circ}$ in the northeastern direction. The density of springs is much lower on slopes consistent with the dip of rock layers (NE) versus that on slopes exposed opposite to the dip of rock layers (SW). These results do not confirm the findings of Corsini et al. (2009) who found a positive relationship between the number of springs and terrain where the dip of rock layers is consistent with the slope gradient, although the dip angle is larger than the slope angle. Corsini et al. (2009) carried out their research in the flyschtype Northern Apennine Mountains in Italy.

Nevertheless, among the small number of springs situated concordantly with the dip of rock layers, there are some high-discharge springs, which is rare for flysch areas. In contrast, springs on the opposite side of the slopes of Polonina Wetlinska are quite numerous, but normally discharge at less than $1 \mathrm{dm}^{3} \mathrm{~s}^{-1}$, with most of the springs discharging less than $0.1 \mathrm{dm}^{3} \mathrm{~s}^{-1}$. Given that the entire Polonina

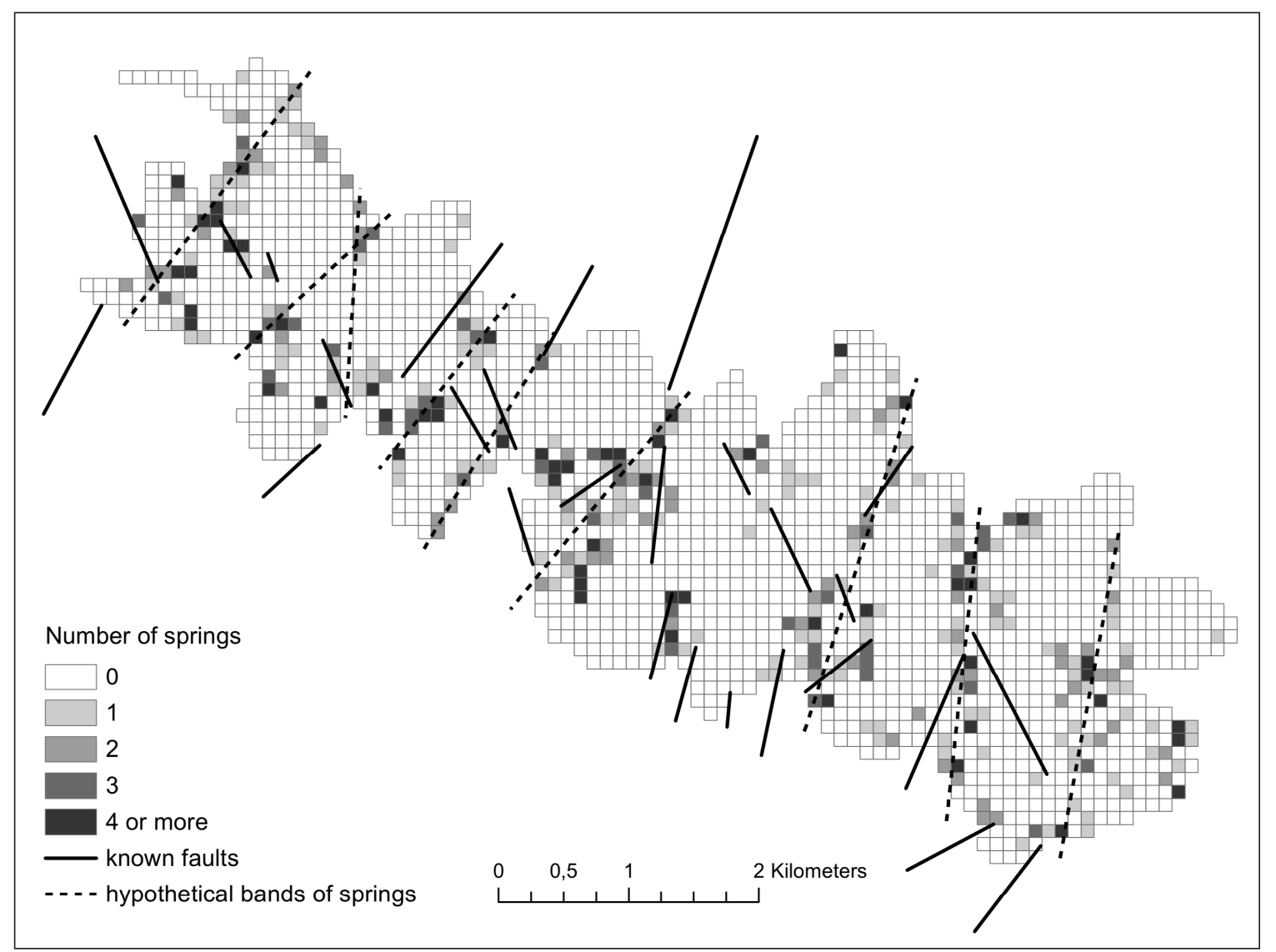

Figure 7. Number of springs in the grid of $100 \times 100$ m polygons in Polonina Wetlinska above 900 m of elevation. (Fault patterns based on: Mastella and Tokarski, 1995). 


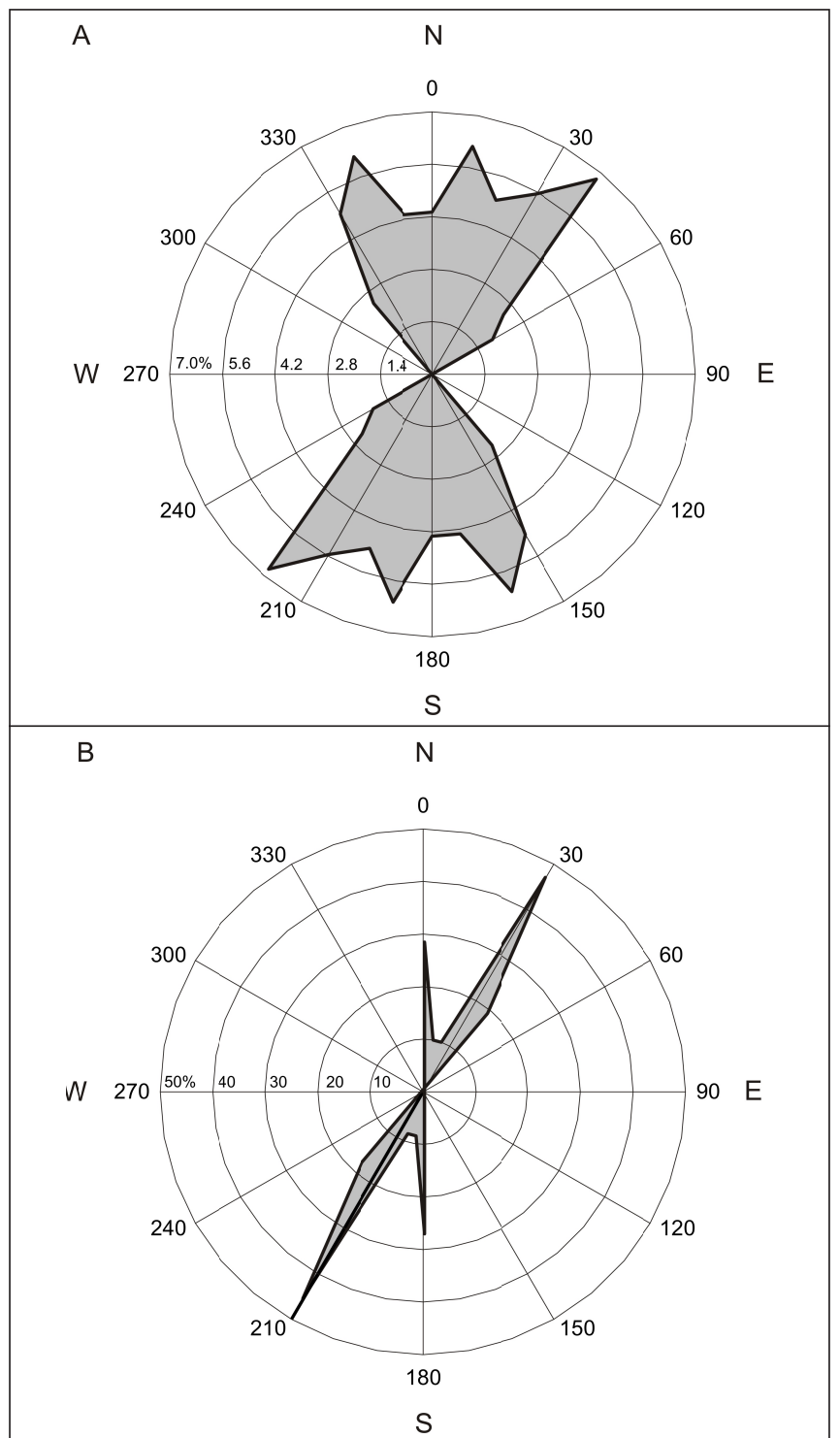

Figure 8. Fault lines $(A)$ and hypothetical bands of springs $(B)$ in Polonina Wetlinska. (Fault patterns based on: Mastella and Tokarski, 1995.)

Wetlinska Massif possesses a similar geological structure (Mastella and Tokarski, 1995), these differences may be explained in terms of the influx of water via underground fractures and the relationship between the dip of rock layers and slope angle. This confirms earlier research findings on the hydrogeology of the Bieszczady Mountains (Chowaniec et al., 1983; Rzonca et al., 2008). Local differences in the arenite/pelite ratio (Corsini et al., 2009) might also have some influence. In addition, lower conductivity on the southern slopes suggests shallower groundwater circulation than that on slopes facing northeast, which may also be associated with the occurrence of a thicker layer of weathering material.

Another factor that may affect spring density is slope angle. Correlation analyses and Kruskal-Wallis tests performed for the upper parts of the studied catchments did not unequivocally confirm statistically significant relationships with slope angle. However, an analysis of variance (ANOVA) for the square polygon grid did show a significant difference in the mean slope angle of areas without springs and areas with three springs. Given that some of the springs serve as channel heads, it is important to review the research literature on the analysis of the determinants of channel head location. Montgomery and Dietrich $(1988,1989,1992,1994)$ stated that the contributing area of a channel head decreases with increasing terrain gradient. Hence, this relationship also applies to some of the investigated springs.

Another pattern observed in the spatial distribution of springs is alignment. Bands of springs often tend to align themselves with minor faults in Polonina Wetlinska (Mastella and Tokarski, 1995). It may be assumed that bands of springs that do not occur along known fault lines are associated with minor systems of subsurface fractures and faults not marked on geological maps (i.e. faults with little displacement), as available cartographic materials with geological information are not detailed enough. As the region is characterized by a relatively stable direction of the powerful shear stress (Jarosinski, 2006), a high density of hydraulically active fissures may be expected. Those fissures may especially augment large springs $\left(>5 \mathrm{dm}^{3} \mathrm{~s}^{-1}\right)$ in the study area. However, the relatively low conductivity of the spring water suggests shallow circulation of the groundwater with short circulation time. This is similar to the results from other ridges of Outer Western Carpathians (Rozenhal, 2009; Lajczak, 2012).

In addition to springs occurring in the fault and fracture zone, some of the investigated springs may occur at the points of contact between layers of sandstone and shale (Fig. 4; Ozdemir, 2011). Earlier research in other parts of the Bieszczady Mountains has shown that the alignment of springs may be linked with the occurrence of faults, as well as strongly fractured adjacent areas, especially isolating faults running down the slope (Rzonca et al., 2008). The relationship between the location of spring and the presence of faults, fractures, and overthrusts in other parts of the world has been also confirmed by Du et al. (2006), Caine et al. (1996), Gambillara et al. (2005), Rowland et al. (2008), Corsini et al. (2009), Ozdemir (2011), and Bense et al. (2013).

In addition, field observations indicate that some springs may originate in mass movement, especially landslides and creeping. Signs of this include areas of debris and rock blocks, irregular slope geometry, and characteristic bending of the lower sections of trees. While no formal research has been done on this subject in the study area, findings by Corsini et al. (2009) for other flysch areas confirm that rock block slides and earth flows do facilitate the emergence of groundwater outflows. Landslide research in flysch areas also suggests the same (Mikoš et al., 2006; Klimeš et al., 2009; Alexandrowicz and Margielewski, 2010), which is not surprising as most of these mass movements are initiated by groundwater processes. Given that the Outer Carpathians (including the Bieszczady), with their unique rock types and specific rock geometry, are especially susceptible to landslides (Raczkowski, 2007), additional research is needed in order to learn more about the relationship between the distribution of springs and mass movement in flysch areas.

\section{Conclusions}

The determinants of the distribution of springs in flysch mountain regions are complex and include geological and geomorphological factors. Significant differences in the distribution of point springs and bog springs on the opposite sides of Polonina Wetlinska are determined in part by the dip of rock layers relative to slope angles. Despite findings to the contrary in other parts of the world (Corsini et al., 2009), this relationship does not manifest itself in a greater density 
of springs on slopes consistent with the dip of rock layers. Instead, the number of springs is smaller, but their discharge is larger. This type of distribution of springs suggests a significant role of underground rock fissures in the recharging process.

The location of springs is also partly linked to the presence of tectonic faults. Bands of springs can be observed in areas close to faults as well as minor but numerous fractures, which are characteristic of flysch in the Outer Carpathians.

Non-geological factors play a minor role in the distribution of springs in flysch regions. Local terrain morphology may play some part in spring density; however, the only statistically significant relationship determined in the course of research has been that between spring density and slope gradient.

\section{Acknowledgements}

The paper was written as part of the research program known as "HydroBieszczady". The authors would like to thank all fieldwork participants.

\section{References}

Alexandrowicz, Z., and Margielewski, M., 2010, Impact of mass movements on geo- and biodiversity in the Polish Outer (Flysch) Carpathians: Geomorphology, no. 123, pp.290-304.

Baker, G., Petriè, M., Parkin, G., and Kogovšek, J., 2001, Surface and groundwater interaction of the Bela stream and Vipava springs in Southwestern Slovenia: Acta Carsologica, v. 30, no. 2, pp. 217-238.

Balon, J., German, K., Kozak, J., Malara, H., Widacki, W., and Ziaja, W., 1995, Regionalizacja fizyczno-geograficzna Polskich Karpat (Physical Geographic Regions of the Polish Carpathians), in Warszynska J., ed., Karpaty polskie. Przyroda, czlowiek i jego dzialalnosc (The Polish Carpathians. Nature, Man, and Human Impact): Wyd. UJ, Kraków: pp. 117-130.

Barfield, B.J., Felton, G.K., Stevens, E.W., and McCann, M., 2004, A simple model of karst spring flow using modified NRCS procedures: Journal of Hydrology, no. 287, pp. 34-48.

Bense, V.F., Gleeson, T., Loveless, S.E., Bour, O., and Scibeck, J., 2013, Fault zone hydrogeology: Earth-Science Reviews, no. 127, pp. 171-192.

Buczynski, S., and Wcislo, M., 2013, Predicting climate-induced changes in groundwater resources on the basis of hydrogeological model research: Case study of the Carpathian flysch belt: Episodes, v. 36, pp. 105-114.

Buczynski, S., and Rzonca, B., 2011, Effects of crystalline massif tectonics on groundwater origin and catchment size of a large spring area in Zieleniec, Sudety Mountains, southwestern Poland: Hydrogeology Journal, no. 19, pp. 1085-1101.

Caine, J.S., Evans, J.P., and Forster, C.B., 1996, Fault zone architecture and permeability structure: Geology, no. 24, pp. 1025-8.

Celle-Jeanton, H., Huneau, F., Travi, Y., and Edmunds, W.M., 2009, Twenty years of groundwater evolution in the Triassic sandstone aquifer of Lorraine: Impact of baseline water quality: Applied Geochemistry, no. 24, pp. 1198-1213.

Chelmicki, W., Jokiel, P., Michalczyk, Z., and Moniewski, P., 2011, Distribution, discharge and regional characteristics of springs in Poland: Episodes, v. 34, no. 4, pp. 244-256.

Chie, G., and Xue, C., 2011, An overview of hydrodynamic studies of mineralization: Geoscience Frontiers, v. 2, no. 3, pp. 423-438.

Chowaniec, J., 2011, The Groundwater of South-Eastern Poland and Problems of Its Protection, in Nalecz, T., Groundwater Management in the East of the European Union. Transboundry Strategies for Sustainable Use and Protection of Resources, Springer: Dordrecht, pp. 71-89.

Chowaniec, J., and Oszczypko N., and Witek K., 1983, Hydrogeologiczne cechy warstw kroœnieñskich centralnej depresji karpackiej (Hydrogeological characteristics of Krosno beds in the Central Carpathian
Depression): Kwartalnik Geologiczny, v. 27, no. 4, pp. 797-810.

Corsini, A., Cervi, F., and Ronchetti, F., 2009, Weight of evidence and artificial neural network for potential groundwater spring mapping: an application to the Mt. Modino area (Northern Apennines, Italy): Geomorphology, no. 111 , pp. $79-87$.

Czarnecka, H. (ed.), 2005, Atlas podzia ${ }^{3} u$ hydrograficznego Polski (Polish Hydrographic Classification): Warszawa, IMGW.

Du, J., Cheng, W., Zhang, Y., Jie, Ch., Guan, Z., Liu, W., and Bai, L., 2006, Helium and carbon isotopic compositions of thermal springs in the earthquake zone of Sichuan, Southwestern China: Journal of Asian Earth Sciences, no. 26, pp. 533-339.

Fiorillo, F., Esposito, L., and Guadagno, F.M., 2007, Analysis and forecast of water resources in an ultra-centenarian spring discharge series from Serino (Southern Italy): Journal of Hydrology, no. 336, pp. 125-138.

Földvary, G.Z., 1988, Geology of the Carpathian Region: World Scientific Publishing Co Pte. Ltd., Singapore.

Gambillara R., Terrana S., Monticelli D., and Giussani B., 2005, Chemical features of the springs and correlations with faults in north-western area of Como Lake basin (Nothern Italy), Geophysical Research Abstracts, v. 7, http://meetings.copernicus.org/www.cosis.net/abstracts/EGU05/ 06957/EGU05-J-06957.pdf

Grasso, D.A., Jeannin, P.-Y., and Zwahlen, F., 2003, A deterministic approach to the coupled analysis of karst springs' hydrographs and chemographs: Journal of Hydrology no. 271, pp. 65-76.

Haczewski, G., Kukulak, J., and Bck, K., 2007, Budowa geologiczna i rzeŸba Bieszczadzkiego Parku Narodowego (Geology and relief of Bieszczady National Park): Prace Monograficzne AP Kraków, no. 468, pp. 1-153.

Jarosinski, M., 2006, Recent tectonic stress field investigations in Poland: a state of the art. Geological Quarterly, v. 50, no. 3, pp. 303-321.

Jaskowiec, B., Placzkowska, E., and Rzonca, R., 2011, Wody podziemne (Groundwater), in Rzonca R., Siwek J., eds, Hydrologia Bieszczadów. Zlewnie Sanu i Solinki powyzej Jeziora Solinskiego (Hydrology of the Bieszczady Mountains. Catchments of the San and Solinka rivers upstream of Solinskie Lake): UJ, Kraków: pp. 59-74.

Jetel, J., 1985, Vertical variations in permeability of flysch rock in the Czechoslovak Carpathians: Geological Quarterly, v. 24(3), pp. 167-178.

Klimeš, J., Baron, I., Pánek, T., Kosacík, T., Burda, J., Kresta, F., and Hradecký, J., 2009, Investigation of recent catastrophic landslides in the flysch belt of Outer Western Carpathians (Czech Republic): progress towards better hazard assessment: Natural Hazards and Earth System Sciences, v. 9, pp. $119-128$

Kukulak, J., 2004, Neotectonics and planation surfaces in the High Bieszczady Mountains (Outer Carpathians, Poland): Annales Societatis Geologorum Poloniae, no. 74, pp. 339-350.

Lajczak, A., Dumnicka, E., Galas, J., Szczesny, B., and Galus-Barchan, A., 2010, Operat ochrony przyrody nieozywionej. Warunki wodne (Description of the abiotic environment. Hydrological features.), in Plan ochrony Bieszczadzkiego Parku Narodowego (Bieszczadzki National Park Protection Plan): Kraków, Krameko, pp. 1-108.

Lajczak, A., 2012, Water circulation and chemical denudation in the upper Skawica River flysch catchment, Western Carpathian Mountains: Zeitschrift für Geomorphologie, vol. 56, no. 1, pp. 069-086.

Lajczak, A., Margielewski, W., Raczkowska, Z., and Swiechowicz, J., 2014, Contemporary geomorphic processes in the Polish Carpathians under changing human impact: Episodes, v. 37, no. 1, pp. 21-32.

Laszczak, E., Ziólkowski, L., and Siwek, J., 2011, Opady i pokrywa œnie ¿na (Precipitation and snow cover), in Rzonca R., Siwek J., eds., Hydrologia Bieszczadow. Zlewnie Sanu i Solinki powyzej Jeziora Solinskiego (Hydrology of the Bieszczady Mountains. Catchments of the San and Solinka rivers upstream of Solinskie Lake): UJ, Kraków, pp. 21-29.

Magal, E., Arbel, Y., Caspi, S., Glazman, H., Greenbaum, N., and Yechieli, Y., 2013, Determination of pollution and recovery time of karst springs, an example from a carbonate aquifer in Israel: Journal of Contaminant Hydrology, no.145, pp. 26-36.

Margielewski, W., 2006, Structural control and types of movements of rock mass in anisotropic rocks: Case studies in the Polish Flysch Carpathians: 
Geomorphology, no.77, pp. 47-68.

Mastella, L., and Tokarski, A., 1995, Mapa geologiczna Bieszczadzkiego Parku Narodowego 1:50000 (Geological Map of Bieszczadzki National Park 1:50000), in Plan ochrony Bieszczadzkiego Parku Narodowego (Bieszczadzki National Park Protection Plan): Manuscript.

Matic, N., Miklavcic, I., Maldini, K., Damir, T., Cuculic, V., Cardellini, C., and Francskovic-Bilinski, S., 2013, Geochemical and isotopic characteristics of karstic springs in coastal mountains (Southern Croatia): Journal of Geochemical Exploration, no.132, pp. 90-110.

Mikoš, M., Brilly, M., Fazarinc, R., and Ribièiè, M, 2006, Strug landslide in W. Slovenia: A complex multi-process phenomenon: Engineering Geology, no.83, pp. 22-35.

Mocior, E., Plenzler, J., Rozmus, M., and Rzonca, B., 2011, Siec rzeczna i charakterystyka zlewni (Drainage networks and characteristics of catchments), in Rzonca R., Siwek J., eds., Hydrologia Bieszczadów. Zlewnie Sanu i Solinki powyzej Jeziora Solinskiego (Hydrology of the Bieszczady Mountains. Catchments of the San and Solinka rivers upstream of Solinskie Lake): UJ, Kraków: pp.31-43.

Montgomery, D.R., and Dietrich, W.E., 1988, Where do channels begin?: Nature, no. 336, pp. 232-234.

Montgomery, D.R., and Dietrich, W.E., 1989, Source areas, drainage density, and channel initiation: Water Resources Research, v. 25, no. 8, pp. 19071918

Montgomery, D.R., and Dietrich, W.E., 1992, Channel initiation and the problem of landscape scale: Science, no. 255, pp. 826-830.

Montgomery, D.R., and Dietrich, W.E., 1994, A physically-based model for topographic control on shallow landsliding: Water Resources Research, v. 30, no. 4 , pp. $1153-1171$.

Nowosad, M., 1995, Zarys klimatu Bieszczadzkiego Parku Narodowego i jego otuliny w œwietle dotychczasowych badan (Outline of the climate of Bieszczadzki National Park and its buffer zone in the light of previous studies): Roczniki Bieszczadzkie, no. 4, pp. 163-183.

Oszczypko, N., 2006, Late Jurassic-Miocene evolution of the Outer Carpathian fold-and-thrust belt and its foredeep basin (Western Carpathians, Poland): Geological Quarterly, v. 50, no. 1, pp. 169-194.

Ozdemir, A., 2011, GIS-based groundwater spring potential mapping in the Sultan Mountains (Konya, Turkey) using frequency ratio, weights of evidence and logistic regression methods and their comparison: Journal of Hydrology, no. 411, pp. 290-308.

Peel, M.C., Finalayson, B.L., and McMahon, T.A., 2007, Updated world map of the Köppen-Geiger climate classification: Hydrology and Earth System Sciences, no. 11, pp. 1633-1644.

Plenzler, J., Bajorek, J., Jaskowiec, B., Kolodziej, A., Rzonca, B., Siwek, J., and Wójcik, S., 2010, Podziemny odplyw jednostkowy w Bieszczadach Wysokich (Specific base flow in the High Bieszczady Mountains): Przeglad Geologiczny, no. 58, pp. 1147-1151.

Prtoljan, B., Kapelj, S., Dukaric, F., Vlahovic, I., and Mrinjek, E., 2012, Hydrogeochemical and isotopic evidences for definition of tectonically controlled catchment areas of the Konavle area springs (SE Dalmatia, Croatia): Journal of Geochemical Exploration, no. 112, pp. 285-296.

Raczkowska, Z., Lajczak, A., Margielewski, W., and Swiechowicz, J., 2012, Recent landform evolution in the Polish Carpathians, in Lóczy, D., Stankoviansky, M., Kotarba, A. (eds.), Recent Landform Evolution. The Carpatho-Balkan-Dinaric Region: Springer-Dordrecht-HeidelbergLondon-New York, pp. 47-103.

Raczkowski, W., 2007, Landslide hazard in the Polish flysch Carpathians: Studia Geomorphologica Carpatho-Balcanica, v. 41, pp. 61-75.

Ronchetti, F., Borgatti, L., Cervi, F., Gorgoni, C., Piccinini, L., Vincenzi, V., and Corsini, A., 2009, Groundwater processes in a complex landslide, northern Apenines, Italy: Natural Hazards and Earth System Sciences, no. 9, pp. 895-904.

Rowland, J.C., Manga, M., and Rose, T.P., 2008, The influence of poorly interconnected fault zone flow paths on spring geochemistry: Geofluids, no. 8, pp. 93-101.

Rozenhal, T., 2009, Silesian Beskidy - selected spring-drainage and waterquality parametres: Beskidy v. 2 no. 2, pp. 165-176.
Rzonca, B., Kolodziej, A., Laszczak, E., Mocior, E., Plenzler, J., Placzkowska, E., Rozmus, M., Siwek, J., Scislowicz, B., Wójcik, S., and Ziolkowski, L., 2008, Zrodla w zlewni górnej Wolosatki w Bieszczadach Wysokich (Springs in the upper Wolosatka river catchment in the High Bieszczady Mountains): Przeglad Geologiczny, no. 56, pp. 772-779.

Schmid, S.M, Bernoulli, D., Fügenschuh, B., Matenco, L., Schefer, S., Schuster, R., Tischler, M., and Ustaszewski, K., 2008, The AlpineCarpathian-Dinaridic orogenic system: correlation and evolution of tectonic units, Swiss Journal Geoscience, no. 101, pp. 139-183.

Siwek, J., Kolodziej, A., Laszczak, E., Mocior, E., Plenzler, J., Placzkowska, E., Rozmus, M., Rzonca, B., Scislowicz, B., Wójcik, S., and Ziolkowski, L., 2009, Geologiczne i geomorfologiczne uwarunkowania wyksztalcenia sieci hydrograficznej w zlewni górnej Wolosatki, Bieszczady Wysokie (Geological and geomorphological determinants of the hydrographic network pattern in the catchment of Upper Wolosatka Stream, High Bieszczady Mts): Kwartalnik AGH Geologia, v. 35, no. 2, pp. 249-261.

Siwek, J., Rzonca, B., Jaskowiec, B., Plenzler, J., and Placzkowska, E., 2013, Natural factors affecting the chemical composition of water in the catchment of Wolosatka Stream (High Bieszczady Mts.), in Kozak, J., Ostapowicz, K., Bytnerowicz, A., and Wyzga, B. (eds.), Integrating Nature and Society towards Sustainability: Springer, pp. 151-159.

Starkel, L., 1966, Evolution of the relief of the Polish East Carpathians in the Quaternary (with the upper San basin as an example): Geographia Polonica, no. 10, pp. 51-89.

Zagana, E., Tserolas, P., Floros, G., Katsanou, K., and Andreo, B., 2011, First outcomes from groundwater recharge estimation in evaporate in Greece with the use of APLIS method, in N. Lambrakis et al., eds, Advances in Research of Aquatic Environment, vol. 2: Springer, Verlag-Berlin Heiderberg, pp. 89-96.

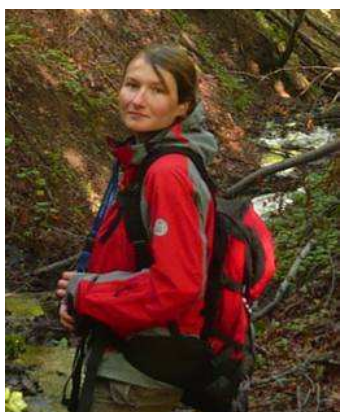

Ewelina Mocior is a $\mathrm{PhD}$ student at the Jagiellonian University in KraKow. She received her MSc degree of geography in 2011. Since 2007 she participated in hydrological and hydrogeological research in Bieszczady Mountains (SW Poland), which included, inter alia, studies of distribution of springs and their properties. Her interests focus on hydrology and landscape ecology of mountains.

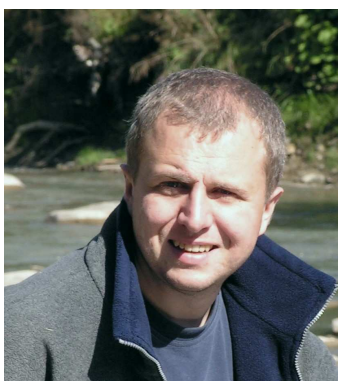

Janusz Siwek, $\mathrm{PhD}$, is a hydrologist at the Jagiellonian University in Krakow. His interest cover the karsthydrology, the human impact on springs discharge and water quality, hydrochemical processes in catchments, the application of GIS in hydrology.

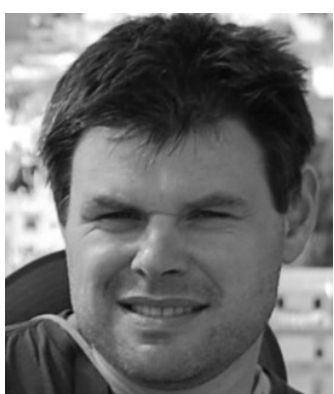

Bartlomiej Rzonca, $\mathrm{PhD}$, is a hydrogeologist at the Jagiellonian University in Krakow, Department of Hydrology. His research interests involve two main subject areas: the broadly defined field of spring research and the hydrogeology of heterogeneous rocks (crystalline and karst). 